\title{
The Effect of Guided Reading Strategy and Reading Interest on Reading Comprehension of Grade VIII Students of SMPN 16 Pekanbaru
}

\author{
Risa Tiarazani ${ }^{1}$, Hamzah $^{2}$, and Jufri ${ }^{3}$ \\ ${ }^{1}$ Universitas Negeri Padang, Padang, Indonesia, $ه$ (email), risatiarazani@gmail.com \\ ${ }^{2}$ Universitas Negeri Padang, Padang, Indonesia, $ه$ (email), hamzahhs@yahoo.com \\ ${ }^{3}$ Universitas Negeri Padang, Padang, Indonesia, $ه$ (email), jufri@gmail.com
}

\begin{abstract}
Reading comprehension is a necessity in foreign language learning, especially on beginner students. Students reading interest would also develop given the time spent on learning different literacy. Researcher wanted to explore it as a contributing factor when engaging them to read and to comprehend. This experimental research study was aimed to describe the effect of guided reading strategy and reading interest on reading comprehension of the students. Sixty-three 8th grade students of SMPN 16 Pekanbaru were divided into experimental class and control class as the subjects for this research. Students' reading comprehension and reading interest were tested by using test and questionnaire for collecting the data of the research. The data were then calculated and analyzed by normality, homogeneity, and hypotheses testing. The result data analysis showed that: (1) guided reading strategy produced better result on students' reading comprehension in comparison to small group discussion; (2) guided reading strategy produced better result on reading comprehension for students with high reading interest in comparison to small group discussion; (3) guided reading did not produce better result reading comprehension for students with low reading interest in comparison to small group discussion; and (4) there was a relationship concerning teaching strategy and interest on reading to students' reading comprehension. It can be concluded that guided reading strategy had a significant impact in aiding students' reading comprehension as compared to small group discussion.
\end{abstract}

\section{Keywords: Guided Reading Strategy, Reading Interest, Reading Comprehension}

\section{INTRODUCTION}

Reading is the skill that can support students in mastering English. In reading, the learners are actively responsible for making sense and catch the idea of the text. Based on Hasbun (2006) in a foreign language class, reading is one of the major fooundation of the input for the students. The ability to read allows them to continue developing other skills that they have acquired in the classroom. Then, through reading a text, the students can relate information from sources to enrich their ability of creating and getting the meaning of the text.

Learners of English as foreign language may sometimes find difficulties in reading an academic text since the activity requires comprehension ability to understand the written text, for the example students tend to read a text not in a full context (one paragraph, one section, etc), and not all of them are able to find the correct information based on the text they have read. Moreover, other problem in reading that is faced by the students is lack of vocabulary. When the students read a text, they will not be able to comprehend a text successfully if they find some unfamiliar words.
Furthermore, to explore the students' knowledge and participation in reading activities during the teaching process in classroom, it is needed to present a strategy that can enhance reading comprehension for students. English teacher needs to be resourseful in choosing the strategy to teach reading. However, based on preliminary observation in SMPN 16 Pekanbaru, the researcher found that the reading activity in the classroom was done monotonously. During the teaching process, teacher asks students to read by themselves for several minutes then they open discussion about unfamiliar words without strategies and students' reading observations. In the final discussion, teacher then inquire certain tasks that consist of several questions in small groups of students. This teaching process cannot be said as a successful approach in order to enhance reading comprehension of the students.

In the relation to reasons why this research is related to students' reading interest with Guided Reading strategy and its effect on students' reading comprehension, the researcher is interested to apply Guided Reading strategy to enhance students' reading comprehension. It is due to this strategy advantages. The guided reading 
procedure if it is applied carefully and correctly, was designed in order to enhance reading comprehension by empasizing organizational skills and cognitive factors, in addition to attitudinal aspects precision in comprehending both explicit and implicit meaning and using selfcorrection. This procedure has been developed by Fountas and Pinnell (2001) who mention that guided reading strategy is designed in order to make creative teaching reading instruction that develops reading proficiency of the students in a form of small group. As an instructional strategy, Guided Reading strategy puts meaning on teacher and students' role differently. Guided reading is defined as taking the chance for thorough intentional selection of texts and further guidance of purposeful activity in order to enhance reading proficiency on teacher part. Meanwhile, for students, guided reading is defined as activity of reading and talking of variety of particularly motivating and fascinating both fiction and nonfiction reading material.

Grabe and Stansberry states that reading interest can be defined as a mean of academic success for students who enjoy reading would usually lead to become a good writer and also a more creative and innovative person. As for the reason this research takes reading interest as moderator variable is it is one of aspects in calculating the ability of the students in learning a language psychologically. It makes reading interest as one of utmost crucial factors to manage students capabilies as it is how they regard while also shape their beliefs of what an effective process of learning is. It means that students can judge themselves whether they are able or not to do something. According to Dalman (2013:141) reading interest is eagerness to understand or comprehend the meaning of certain selection. In this case, the students who have higher eagerness and motivation with stronger effort will be concluded to have high reading interest. That is why it will affect students' performance and comprehension with high or low reading interest.

This research would like to determine the effect of guided reading strategy and reading interest on reading comprehension especially on recount text. Formulations of problems are specified as the following :

1.Does Guided Reading strategy produce better result on students' reading comprehension than small group instruction at grade VIII students of SMPN 16 Pekanbaru?

2.Does Guided Reading strategy produce better result on students' reading comprehension than small group instruction for students with high reading interest?

3.Does Guided Reading strategy produce better result on students' reading comprehension than small group instruction for students with low reading interest?

4.Is there any relation on both teaching strategies and reading interest to students' reading comprehension on grade VIII students of SMPN 16 Pekanbaru?

\section{METHOD}

The type of the researh in this study is quasiexperimental research. The researcher investigated the effect of independent variable which were Guided Reading strategy and students' reading interest as moderator variable toward the dependent variable namely students' reading comprehension on recount texts. The population of the reseach was grade VIII students of SMPN 16 Pekanbaru academic year 2017/2018 with the total of 283 students. While, to get the samples in this research, the researcher applied cluster random sampling and VIII.3 was chosen to be the experimental class and VIII.6 was chosen to be the control class.

There are two instruments that was used in this research. They were reading of recount text comprehension test and questionnaire for reading interest of the students. The normality and homogeneity of population were tested from students' score in reading by applying Liliefors formula for normality testing and $\mathrm{F}$ test for homogeneity testing. As for hypotheses testing, the researcher used t-test for hypothesis 1,2 and 3 and Two Ways ANOVA for hypothesis 4.

\section{RESULT AND DISCUSSION}

Guided reading strategy produced better result on students' reading comprehension in comparison to small group discussion

For the first hypothesis, according to the outcome of statistical analysis to reading comprehension of students, it was found that T-test for both experimental and control class was higher than Ttable. As the result Null Hypothesis is discarded. Guided reading strategy produces better result on students' reading comprehension in comparison to small group discussion.

Table 1. The Result of Analysis on Reading Comprehension of the Students in both Experimental Class and Control Class

\begin{tabular}{ccc}
\hline Data & $\begin{array}{c}\text { Guided } \\
\text { Reading Strategy }\end{array}$ & $\begin{array}{l}\text { Small } \\
\text { Discussion }\end{array}$ \\
\hline $\mathrm{N}$ & 31 & 31 \\
\hline $\mathrm{x}-$ & 72.65 & 68.87 \\
\hline $\mathrm{T}_{\text {observed }}$ & 2.665 & \\
\hline $\mathrm{T}_{\text {table }}$ & 2.000 & \\
\hline Conclusion & $\mathrm{T}_{\text {observed }} \mathrm{T}_{\text {table }}$ & \\
& $\mathrm{H}_{\mathrm{a}}$ accepted & \\
\hline
\end{tabular}

Based on the table above, guided reading strategy meets its purpose in aiding students to successfully comprehend a text. According to Wyse and Jones (2007), the important aspects of guided reading are: (i) using several copies of reading material, in the small group discusion for respective students, (ii) books are matched to the ability levels of the group, (iii) it involves introduction to a new text or reflections on a known text, or section of text, read previously (iv) apt to the discussion, the teacher encourage students in order to become independent readers with questions as teachers' prompts, (v) the teacher works with a different text at various levels of text, on each day of the week. It is clear 
that guided reading strategy creates opportunity for students to widen their horizon of literacy by finding the best learning at their own pace. While it is important to make their own strategy in comprehending a text, English teacher can start to guide their reading habit towards independency.

Besides, guided reading strategy involves problem solving for the students to gradually comprehend complex sentence structure and to get the meaning of unfamiliar words. This notion is in accordance to Iaquinta (2006) who mention guided reading strategy is an instructional strategy which can be performed to both dependent and independent readers, which carries three significant aims: to fulfill multiple variety of instructional needs of the whole learners, to enable the students in developing their powers in order to read material with increased difficulty while also being accurate and fluent; to build meaning as well as excersizing problem solving strategies to find the meaing of difficult words which contains structures of complex sentence, and comprehend the unfamiliar contexts or ideas.

In conclusion, from all of guided reading strategy advantages above, this teaching strategy significantly affects students' reading comprehension. Various studies on guided reading strategy also reveals the same encouraging results. The students learn selfmonitoring as well as decision-making.

Guided Reading Strategy produced better result on reading comprehension for students with high level of reading interest in comparison to small group discussion

For the second hypothesis, according to the outcome of statistical analysis to reading comprehension of students, it was found that T-test for both experimental and control class was higher than Ttable. As the result $\mathrm{HO}$ is rejected. Students with high level of reading interest which were using guided reading strategy as intructional method produces better result in comparison to small group discussion

Table 2. The Result of Analysis of Students' Reading Comprehension of both Experimental and Control Class with High Reading Interest

\begin{tabular}{ccc}
\hline Data & $\begin{array}{c}\text { Guided } \\
\text { Reading Strategy }\end{array}$ & $\begin{array}{l}\text { Small } \\
\text { Discussion }\end{array}$ \\
\hline $\mathrm{N}$ & 8 & 8 \\
\hline $\mathrm{x}-$ & 76.75 & 70.63 \\
\hline $\mathrm{T}_{\text {observed }}$ & 4.383 & \\
\hline $\mathrm{T}_{\text {table }}$ & 2.145 & \\
\hline \multirow{2}{*}{ Conclusion } & $\mathrm{T}_{\text {observed }}>$ Table \\
& $\mathrm{H}_{\mathrm{a} \text { accepted }}$ & \\
\hline
\end{tabular}

Students with high level of reading interest who receive intruction of guided reading strategy exceed scores of those taught by small group discussion due to their drive in comprehending their desired texts or books. Walberg and Tsai (1984) also states reading interest has a lot to do with the success in both school and life of learners. Reading interest acts as the driving force that makes them eager to learn. Students with high level of reading interest will likely to give an attempt at reading books and other materials for either pleasure or academic purposes.

Therefore, students with high reading interest, while being guided to comprehend reading material efficiently by the teacher have better results in comparison to the traditional small group discussion.

Guided reading did not produce better result on reading comprehension for students with low reading interest in comparison to small group discussion

For the third hypothesis, according to the outcome of statistical analysis to reading comprehension of students, it was found that T-test for both experimental and control class was lower than Ttable. As the result H0 is accepted. Students who have low reading interest who received instruction of guided reading strategy did not produces better result in comparison to small group discussion.

Table 3. The Result of T-test Analysis of Students' Reading Comprehension in Experimental and Control Class with Low Reading Interest

\begin{tabular}{cll}
\hline Data & $\begin{array}{l}\text { Guided } \\
\text { Reading } \\
\text { Strategy }\end{array}$ & $\begin{array}{l}\text { Small } \\
\text { Discussion }\end{array}$ \\
\hline $\mathrm{N}$ & 8 & 8 \\
\hline $\mathrm{x}-$ & 69.25 & 71.63 \\
\hline $\mathrm{T}_{\text {observed }}$ & -1.272 & \\
\hline $\mathrm{T}_{\text {table }}$ & 2.145 & \\
\hline Conclusion & \multicolumn{2}{|c}{$\mathrm{T}_{\text {observed }} \mathrm{T}_{\text {table }}$} \\
& $\mathrm{H}_{\mathrm{a}}$ rejected \\
\hline
\end{tabular}

Students with low reading interest are prone to difficulties in analyzing, problem solving and comprehending reading materials given both inside and outside of the classroom. In contrast, guided reading strategy are focused in directing students to actively searching and finding their best learning and comprehending habits in order to apply it whenever they encounter difficulties reading a text.

Thus, the students with have low reading interest do not have much efforts in finding the unfamiliar words nor comprehending the reading materials. However, it is important to keep engaging them to explore their favorite reading platform for starter. Gradually, they will develop the higher reading interest based on the right guidance to comprehend certain text material.

In comparison to small group discussion, it offers limited opportunities for either instruction or learning. English teacher gives several commands to complete tasks in small group with little explanation. Although the students have limited choice in selecting the method, they are given the specific details to pay attention to and obvious drilling. It can serve as task completing for a good result. As Slavin (2005) states that some principles which should be considered in small group activities. It forces students to take active role and it must be 
stimulating and provocating. The success of small group discussion depends on the teacher's leading and the suitable material which is implemented in systematic order. Thus, small group discussion is good for students in practicing, or discussing a material or subject in order to meet certain learning objectives.

There is a relation on both techniques and reading interest to students' reading comprehension.

Table 4. Result of Two Ways Anova

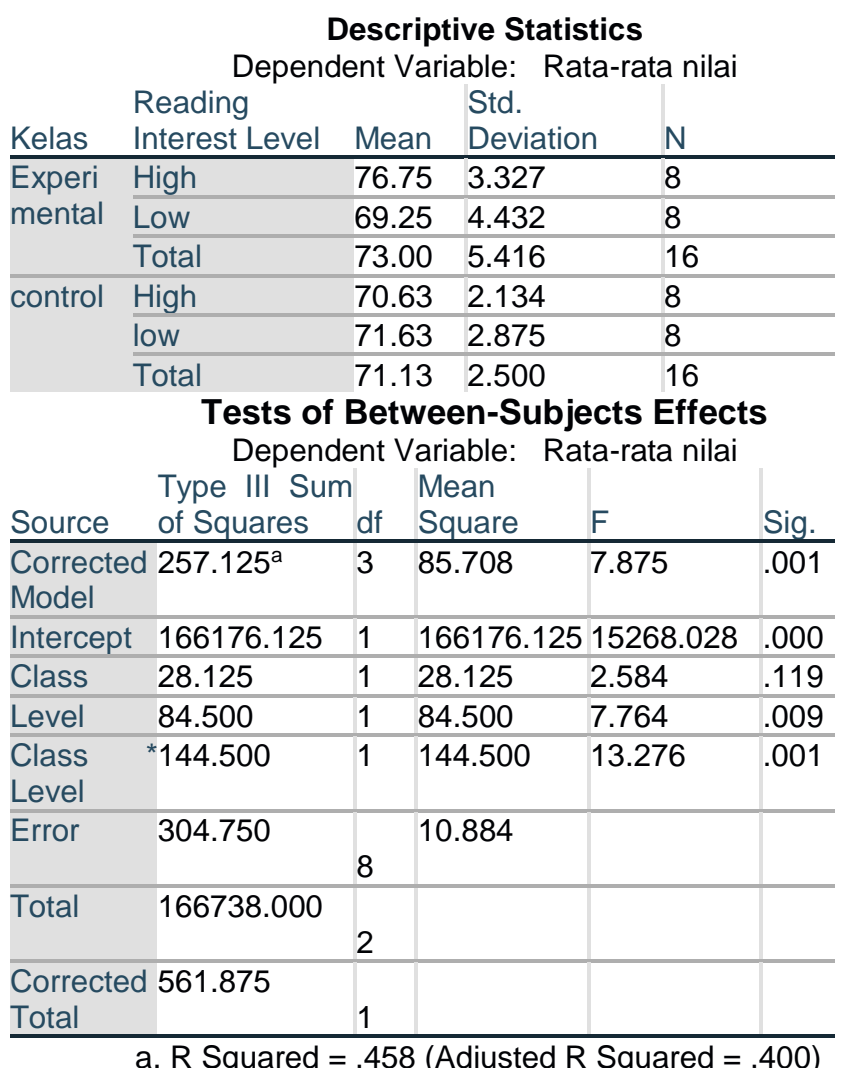

Guided Reading strategy technique is not appropriate for the students with low reading interest. Based on the difference of average score of students' reading comprehension above, it can be seen that one of them is an effective teaching strategy. From this statistics, another conclusion that can be drawn is that there is a relation of the use of teching strategies (Guided Reading strategy and Small Group Discussion) and reading interest to students' reading comprehension. Then, there is also significant difference between Guided Reading strategy given to high and low reading interest students. It indicates that both strategies influence the reading comprehension with different level of students' reading interest.

\section{CONCLUSION}

Guided reading strategy produced better result on students' reading comprehension in comparison to small group discussion. It is due to its scaffolded specific reading strategies prior to the guided reading lesson that the students have a better understanding on reading. Problem-solving and higher-order thinking skills are enhanced while teaching how to comprehend a text through guided reading strategy

Then, guided reading strategy produced better result on students' ability to comprehend texts for those with high level of reading interest in comparison to small group discussion. Next, Guided reading did not produce better result on students' ability to comprehend texts for students who have low level of reading interest in comparison to small group discussion. It is clear that a good teaching strategy should be followed by a good nature driving force for it to be effective and efficient. Finally, there is a relation on both techniques and students' reading interest to students' ability to comprehend texts. Both strategy and moderator variable are integrated in order to create a good classroom atmosphere.

\section{ACKNOWLEDGMENTS}

The greatest gratitude to Allah SWT and shalawatu wassalam to Muhammad SAW that I am able to finish this journal as one of the prerequisite of obtaining a degree of Magister of Education. My deepest love and gratitude to both of my parents and family for their endless support and encourage. Appreciation and gratitude to both of my supervisor Dr. Hamzah, M.A., M.M. and Dr. Jufri, M.Pd. for their guidance and support during the process of this thesis writing.

\section{REFERENCES}

[1] Dalman (2013) Keterampilan Membaca. Jakarta: Rajawali Press

[2] Fountas, I.C., and Pinnell, G.S. (2001) Guiding readers and writers, Grades 3-6: Teaching comprehension, genre, and content literacy. Portsmouth, NH: Heinemann.

[3] Grabe, W. (2003) Reading-writing relations: L2 perspectives on research and practice. In B. Kroll (Ed.), Research on second-language writing (pp. 242-262). New York: Cambridge University Press.

[4] Hasbun, H. (2006) The role of vocabulary acquisition in students' attitudes towards reading. Revista Communication. Vol.15, No.1, pp.37-45.

[5] Iaquinta, Anita. (2006) Guided Reading: A Research-Based Response to the Challenges of Early Reading Instruction. Early Childhood Education Journal. 33(6),p 413-418.

[6] Slavin, Robert E. (2005) Cooperative Learning. London: Allymand Bacon

[7] Walberg, H. J., \& Tsai, S. L. (1985) Correlates of reading achievement and attitude: A national assessment study. Journal of Educational Research, 78(3), 159-167.

[8] Wyse, Dominic., \& Jones, Russel (2007) Teaching English, Language and Literacy. New York: Routledge 